\title{
Alternativo
}

\section{A GLÂNDULA TIMO E AS TÉCNICAS DE CURA DA MEDICINAL HOLÍSTICA TRADICIONAL}

Bernardo Melgaço da Silva (1)

Desde 1988 venho me questionando sobre a relação entre o Amor metafísico (que vivenciei uma única - e inesquecível! - vez) e o Amor físico (que experimentei centenas de vezes!). E já se passaram mais de 20 anos da minha experiência mística e holística com o Amor Cósmico e, de lá para cá, sempre me indaguei sobre aquele fenômeno maravilhoso e misterioso que se manifestou no centro do meu peito em 1988.

Eu sabia desde o primeiro dia da experiência que tive, que havia pelo menos dois planos de experiência/vivência acontecendo simultaneamente: o físico e o metafísico. E que o plano metafísico (dos chacras), era a raiz da energia humana - o nosso lado transcendente. E o plano físico era o meio, o caminho de realização física e material - o nosso lado imanente.

Mas, o que me intrigava era saber qual parte do plano físico estava de fato ligado ao plano metafísico do chacra cardíaco. Hoje, após todos esses longos anos de incertezas e questionamentos, tenho que admitir que a resposta está nas glândulas, principalmente a Timo. Ela tem um papel vital no processo de regulação do humor; no processo imunológico e; no processo de refinamento das emoções, entre tantas outras funções.

Gostaria de sugerir um desafio acadêmico aos médicos e pesquisadores em geral, que possuem mentes abertas: pesquisem a relação entre a glândula Timo, o chacra cardíaco e o sistema imunológico. Acredito que nessa relação, estão as respostas para várias doenças tais como a AIDs, o Câncer, etc. Essa hipótese está baseada numa vivência mística que tive em 1988. Eu vivenciei em meu peito o fenômeno da interligação dos planos energéticos sutil (dos chacras) e concreto (glândulas Timo, Pineal e outras).

Assim, parto de uma experiência íntima para a formulação de uma hipótese e não, o caminho contrário (da hipótese para o teste ou experiência), que é muito comum nos processos de pesquisa científica. Sugiro aos médicos e todas as pessoas (pesquisadoras ou não) ligadas às áreas de saúde, que estudem o conteúdo do livro "Medicina Vibracional: A 
Medicina Do Futuro", do médico-pesquisador Dr. Richard Gerber. Nesse livro vocês encontrarão subsídios técnicos e científicos para buscarem uma conexão entre a TIMO, o CHACRA e o SISTEMA IMUNOLÓGICO.

A ciência precisa alargar seus horizontes como já vem fazendo muito bem nos campos de conhecimento da genética, física quântica e a astrofísica. Mas, mesmo assim, precisamos urgentemente de hipóteses metafísicas para descortinarmos um mundo de fenômenos sutis, responsáveis por boa parte das doenças crônicas.

Sinto intuitivamente que quando os cientistas decidirem testar a hipótese da causalidade descendente (do plano metafísico para o plano físico, ou do plano qualitativo para o plano quantitativo), daremos um passo gigantesco fenomenal para explicarmos uma série de doenças de origem ainda desconhecida. A ciência moderna ainda não sabe penetrar no mundo essencial qualitativo das energias sutis das emoções humanas. Essa crítica foi realizada em minha monografia de dissertação de mestrado defendida em 1992 na COPPE/UFRJ. Em outras palavras, as energias descobertas pela ciência ainda são insuficientes para identificarem um conjunto de fenômenos causadores de anomalias no campo energético do sistema, complexo e multidimensional, da consciência e das transformações que ocorrem na relação entre psique e corpo físico.

Uma coisa eu descobri e constatei em minhas experiências íntimas (vivências), foi que: a forma como vemos um objeto (seja ele físico ou metafísico) afeta o objeto observado (essa tese é também uma afirmativa da física quântica moderna). Isso implica dizer que o universo guarda segredos no próprio modo e ato de se observar um fato ou fenômeno. Ou seja, não existe neutralidade no campo científico e nem no campo do senso comum.

O tempo todo, estamos afetando o mundo e somos afetados pelos outros a nossa volta. Existe uma fronteira invisível entre o que nos é desconhecido e o que já é conhecido. A transição de um lado para o outro acontece em planos da percepção em que estamos agindo ou construindo - de um modo geral estamos inconscientes na ocasião da transição. As doenças, enquanto fenômenos naturais, são também criadas pela forma como nos conduzimos na relação que temos com as multidimensionalidades das energias que circulam entre o homem e a natureza. Somos seres extremamentes sensíveis, plurais e abertos para o cosmos.

Nesse contexto, todos os fenômenos nos afetam (direta ou indiretamente) sem que tenhamos sensibilidade para vermos as suas origens no nascimento deles. Por exemplo, as explosões solares (muito comuns na superfície do sol) afetam os sistemas de radar dos pássaros, baleias, seres humanos, celulares, satélites etc. 
Então a nossa realidade nos guarda o maior mistério que é a essência ou qualidade dos fenômenos. O essencial é invisível porque não se mede quantitativamente. As doenças são visíveis pelos seus efeitos, o princípio delas é desconhecido na sua origem. Nesse sentido, precisamos adotar uma nova abordagem científica que seja compatível com o objeto ou fenômeno observado. Pois, só vemos o que é compatível com o nosso nível de consciência. O comum é o centro da curva normal (na área da estatística), os extremos são incompreensíveis e invisíveis para o nosso olhar viciado.

Eu vou revelar aqui uma descoberta que fiz em 1988: o que chamamos de impressões digitais são na verdade centros de energia (chacras (ou chakras) menores), verdadeiros receptores ou antenas captadoras de energias sutis cósmicas. Pergunto, então: quantos dos meus leitores alcançarão essa verdade vivenciada por mim em 1988? O Amor tão falado por Jesus Cristo está situado no centro do peito, e tem uma relação direta com a glândula Timo. É por isso, que alguns autores e pesquisadores afirmam que a falta de amor no mundo é a maior desgraça que afeta a paz e a saúde humana em todos os tempos. Ou seja, quando esse chacra principal não está funcionando bem, a glândula Timo também não está em sua potencialidade nos resguardando na sua relação com o sistema imunológico. E ai ficamos vulneráveis - sem defesa!

\section{Sobre o autor:}

(1) Bernardo Melgaço da Silva é Professor da Universidade Regional do Cariri - URCA e Pesquisador do Núcleo de Estudos Sobre Ciência, Espiritualidade e Filosofia - NECEF.

E-mail: bernardomelgaco@gmail.com

Site do autor: http://bernardomelgaco.blogspot.com

\section{Como citar este artigo (Formato ISO):}

SILVA, B.M. A Glândula Timo e as técnicas de cura da medicina holística tradicional. Id on Line Revista de Psicologia, Novembro de 2010, vol.1, no.12, p.67-69. ISSN 1981-1189. 